\title{
The agglutination of $\beta$-haemolytic streptococci by lectins
}

\author{
J. T. C. KELLENS, J. A. JACOBS*, W. J. PEUMANS $\dagger$ and ELLEN E. STOBBERINGH \\ Department of Medical Microbiology, University of Limburg, Maastricht, The Netherlands, *Department of Medical \\ Microbiology, University Hospital, Maastricht, The Netherlands and +Laboratory of Phytopathology and Plant \\ Protection, Catholic University, Leuven, Belgium
}

\begin{abstract}
Summary. The ability of 25 lectins, isolated from different plants and fungi, to agglutinate 95 clinical isolates of $\beta$-haemolytic streptococci was examined. Cell suspensions were untreated, trypsin-treated or boiled at $\mathrm{pH} 2 \cdot 0$. None of the 95 untreated cell suspensions gave a visible reaction with any of the lectins. When the cells were trypsinised, 42 strains were agglutinated with one or more lectin and after boiling at $\mathrm{pH} \mathrm{2,} \mathrm{all} \mathrm{the} \mathrm{strains} \mathrm{were} \mathrm{agglutinated.} \mathrm{After}$ treatment with trypsin, 20 different agglutination patterns were observed, and after boiling, 19 patterns, four of which were similar. A correlation was found between Lancefield group C and some of these patterns. Some lectins reacted specifically with group $\mathrm{C}$ streptococci; DBA and WFA, both specific for D-GalNAc, DSA, a GlcNAc-specific lectin, and RPA, which showed a complex specificity, reacted only with group $\mathrm{C}$ strains. Furthermore, the lectin of Maackia amurensis reacted with $50 \%$ of group B streptococci only. Agglutination assays with lectins were reproducible, easy to perform, relatively inexpensive and, therefore, applicable to studies of cell-wall structure and epidemiology of $\beta$-haemolytic streptococci.
\end{abstract}

\section{Introduction}

Lectins are sugar-binding proteins or glycoproteins of non-immune origin that agglutinate or precipitate glycoconjugates. ${ }^{1}$ According to their sugar-binding specificity, lectins can be classified into five groups on the basis of their affinity for (i) glucose (Glc) and mannose (Man), (ii) galactose (Gal) and $N$-acetyl-Dgalactosamine (D-GalNAc), (iii) $N$-acetyl-glucosamine (GlcNAc), (iv) L-fucose (L-Fuc) or (v) sialic acids. ${ }^{2}$ They can bind to carbohydrate residues of bacterial surface components such as peptidoglycan, teichoic acids, lipopolysaccharides and capsular material. ${ }^{3}$ In the past, many lectins have been used to study cellsurface carbohydrates of different bacterial species.

Lectins play an important role in studies on the identification of surface structures of streptococci. Lectins from Helix pomatia, Glycine max, Dolichos biflorus, and Wisteria floribunda react specifically with group $\mathrm{C} \beta$-haemolytic streptococci, but not with streptococci of other serogroups. ${ }^{4,5}$ The lectin from Cepaea hortensis agglutinated all group B streptococcal strains containing the sialic acid type-specific polysaccharide, whereas other streptococci of group $B$ and other groups, as well as other bacteria-even those containing sialic acid-were not agglutinated. ${ }^{6}$ Group B streptococci were also specifically recognised by the lectins of Lycopersicon esculentum and Solanum tuberosum, whereas the lectin of Datura stramonium, another solanaceous plant, did not agglutinate group

Received 19 May 1993; revised version accepted 3 June 1993.
B streptococci. ${ }^{7}$ Furthermore, the use of the Lotus tetragonolobus lectin in Western blotting indicated the presence of fucosyl residues in the cell walls of Enterococcus faecalis, and lectin probes of wheat germ agglutinin, Concanavalin-A, and soybean agglutinin demonstrated the presence of $N$-acetylneuraminyl, glucosyl, or mannosyl and $N$-acetylgalactosaminyl residues on the surface of this species. ${ }^{8}$

The usefulness of lectin typing for epidemiological purposes for staphylococci, streptococci, neisseria, campylobacters and enterobacteria has been discussed in several studies. ${ }^{3,9-12}$

This report describes the agglutination by 25 different lectins from plants and fungi of 95 clinical isolates of $\beta$-haemolytic streptococci of different Lancefield groups and assesses the usefulness of lectin agglutination for epidemiological typing.

\section{Materials and methods}

\section{Bacterial strains}

In the period from Nov. 1992 to Feb. 1993, 95 strains of $\beta$-haemolytic streptococci were isolated from clinical samples from the respiratory tract (7), urogenital tract (15), blood (10), skin and soft tissues (61) and central nervous system (2). The strains were stored at $-70^{\circ} \mathrm{C}$ in peptone-glycerol (proteose peptone no. 2 $1 \% \mathrm{w} / \mathrm{v}$; glycerin $8 \% \mathrm{v} / \mathrm{v}$ ).

\section{Lancefield grouping}

Lancefield grouping for groups A, B, C, F and G 
Table I. Lectins used in the agglutination assays

\begin{tabular}{|c|c|c|c|c|c|}
\hline No. & Code & Species name & Common name & Carbohydrate specificity & Reference \\
\hline 1 & PNA & Arachis hypogaea & Peanut & $\beta$-D-Gal $(1,3) \mathrm{D}-\mathrm{GalNAc}$ & 13 \\
\hline 2 & AMA & Arum maculatum & Lords and ladies & Complex & UP \\
\hline 3 & AMA II & Arum maculatum & Lords and ladies & Complex & UP \\
\hline 4 & APA & Aegopodium podagraria & Ground elder & D-GalNAc & 14 \\
\hline 5 & ASA & Allium sativum & Garlic & $\alpha(1,3)$ Man & 15 \\
\hline 6 & AUA & Allium ursinum & Ramsons & $\alpha(1,3) \mathrm{Man}, \alpha(1,6) \mathrm{Man}$ & 15 \\
\hline 7 & BDA & Bryonia dioica & White bryony & D-GalNAc & 16 \\
\hline 8 & DSA & Datura stramonium & Thorn-apple & $\mathrm{D}-(\mathrm{GlcNAc})_{2}$ & 17 \\
\hline 9 & GNA & Galanthus nivalis & Snowdrop & $\alpha(1,3)$ Man & 15 \\
\hline 10 & IRA & Iris reticulatum & Iris & D-GalNAc & UP \\
\hline 11 & MAA & Maackia amurensis & Maackia & Neu5Ac- $\alpha(2,3) \mathrm{Gal}$ & 18 \\
\hline 12 & NPA & Narcissus pseudonarcissus & Daffodil & $\alpha(2,6)$ Man & 15 \\
\hline 13 & RPA & Robinia pseudoacacia & Black locust & Complex & 19 \\
\hline 14 & CCL & Ceratobasidium cornigerum & & D-GalNAc & 20 \\
\hline 15 & RSA & Rhizoctonia solani & & D-GalNAc & 20 \\
\hline 16 & SMyL & Sclerotinia myabaena & & D-GalNAc & 21 \\
\hline 17 & SSL & Sclerotinia sclerotiorum & & D-GalNAc & 21 \\
\hline 18 & SNA & Sambucus nigra & Elder & Neu $5 A c-\alpha(2,6)$ GalNAc & 22 \\
\hline 19 & SNA II & Sambucus nigra & Elder & D-GalNAc & 22 \\
\hline 20 & TL & Tulipa & Tulip & D-GalNAc & 23 \\
\hline 21 & WFA & Wisteria floribunda & Wisteria & D-GalNAc & 24 \\
\hline 22 & WGA & Triticum aestivum & Wheat germ & D-(GlcNAc $)_{4}$, NeuNAc & 25 \\
\hline 23 & Con-A & Canavalia ensiformis & Jack bean & $\alpha$-D-Man, $\alpha$-D-Glc & 26 \\
\hline 24 & DBA & Dolichos biflorus & Horse gram & D-GalNAc & 27 \\
\hline 25 & VAA & Viscum album & Mistletoe & $\beta$-D-Gal & 28 \\
\hline
\end{tabular}

UP, unpublished.

was performed with the Streptex latex agglutination kit (Wellcome Diagnostics) according to the manufacturer's instructions.

\section{Lectins}

Lectins from different plants and fungi were extracted, isolated by affinity chromatography and further purified as described previously. ${ }^{13-28}$ In table I the lectins are listed, along with the scientific name and the common name of the species from which they were isolated, their carbohydrate specificity and a relevant reference. Lectin solutions of $1 \mathrm{mg} / \mathrm{ml} \mathrm{w} / \mathrm{v}$ in phosphate-buffered saline (PBS; $1.5 \mathrm{mM} \mathrm{KH} \mathrm{KHO}_{4}$,

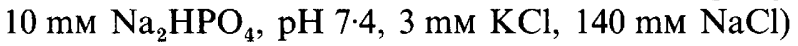
were stored at $-20^{\circ} \mathrm{C}$ until use.

\section{Agglutination assays}

Bacterial strains were grown in $50 \mathrm{ml}$ of ToddHewitt broth for $18 \mathrm{~h}$ at $37^{\circ} \mathrm{C}$ in air with $\mathrm{CO}_{2} 5 \% \mathrm{v} / \mathrm{v}$. Cells were collected by centrifugation at $3000 \mathrm{~g}$ for $15 \mathrm{~min}$, washed in PBS and resuspended in PBS, adjusting the suspensions to an $A_{620}$ of 5 in a spectrophotometer.

Three $\mathrm{ml}$ of each strain suspension were left untreated, $3 \mathrm{ml}$ treated with trypsin and $3 \mathrm{ml}$ boiled in glycin $\mathrm{HCl}$ at $\mathrm{pH} 2$. For trypsin treatment, suspensions were incubated with trypsin $0.1 \mathrm{mg} / \mathrm{ml} \mathrm{w} / \mathrm{v}$ for $1 \mathrm{~h}$ at $37^{\circ} \mathrm{C}$; the cells were washed in PBS to remove the trypsin and resuspended in $3 \mathrm{ml}$ of PBS. For glycin$\mathrm{HCl}$ treatment, the suspensions were centrifuged at $3000 \mathrm{~g}$ for $15 \mathrm{~min}$, resuspended in $3 \mathrm{ml}$ of $0.25 \mathrm{M}$ glycin-
$\mathrm{HCl}$ buffer, $\mathrm{pH} 2 \cdot 0$, and boiled for $15 \mathrm{~min}$. The cells were then washed with PBS and resuspended in $3 \mathrm{ml}$ of PBS.

Agglutination assays were performed in small glass tubes in a final volume of $0.1 \mathrm{ml}$ containing $10 \mu \mathrm{l}$ of lectin solution and $90 \mu \mathrm{l}$ of cell suspension. A negative control was included for each strain by adding $10 \mu \mathrm{l}$ of PBS instead of the lectin solution. After the mixtures had been left for $1 \mathrm{~h}$ at room temperature, agglutination was assessed visually.

\section{Reproducibility}

Reproducibility of lectin agglutination was tested with five strains, one each of Lancefield groups A, B, and $G$ and two of group $C$. Each strain was subcultured five times and the agglutination assays were performed as described above.

\section{Results}

Reproducibility was tested with five strains. Lectin agglutination patterns were not altered on subculture. However, within the same strain there were differences in the agglutination pattern according to the pretreatment of the bacteria (results not shown).

Without pre-treatment, auto-agglutination of the bacteria prevented visualisation of the lectin agglutination. However, trypsinisation or boiling revealed different agglutination patterns. When the bacteria were treated with trypsin, 42 strains reacted with one or more lectins, giving rise to 20 different agglutination patterns (table II). After boiling the cells in glycin- 
Table II. Patterns of lectin agglutination with trypsin-treated cells and their distribution within Lancefield groups

\begin{tabular}{|c|c|c|c|c|c|c|c|c|c|c|c|c|c|c|c|c|c|c|c|c|c|c|}
\hline \multirow{2}{*}{$\begin{array}{l}\text { Pattern } \\
\text { no. }\end{array}$} & \multicolumn{18}{|c|}{ Agglutination with lectins* } & \multicolumn{4}{|c|}{$\begin{array}{l}\text { Number of strains } \\
\text { within Lancefield group }\end{array}$} \\
\hline & 1 & 4 & 7 & 8 & 9 & 10 & 11 & 13 & 14 & 15 & 16 & 17 & 18 & 19 & 21 & 22 & 23 & 24 & $\begin{array}{c}\mathrm{A} \\
(29)\end{array}$ & $\begin{array}{c}\text { B } \\
(22)\end{array}$ & $\begin{array}{c}\mathrm{C} \\
(11)\end{array}$ & $\begin{array}{c}G \\
(33)\end{array}$ \\
\hline 1 & - & + & - & - & - & - & - & - & - & - & - & - & - & - & - & - & - & - & 1 & 0 & 0 & 0 \\
\hline 2 & - & - & - & - & - & - & - & - & - & - & - & - & - & - & - & + & - & + & 2 & 0 & 0 & 0 \\
\hline 3 & - & - & - & - & - & - & - & - & - & - & - & - & - & - & - & + & + & + & 2 & 0 & 0 & 0 \\
\hline 4 & - & - & - & - & - & - & - & - & - & - & - & - & - & - & - & + & - & - & 3 & 1 & 0 & 0 \\
\hline 5 & - & - & - & - & - & + & - & - & - & - & - & - & - & - & - & - & - & - & 0 & 1 & 0 & 0 \\
\hline 6 & - & - & - & - & - & - & + & - & - & - & - & - & - & - & - & - & - & - & 0 & 6 & 0 & 0 \\
\hline 7 & + & - & - & - & - & - & + & - & - & - & - & - & - & - & - & - & - & - & 0 & 1 & 0 & 0 \\
\hline 8 & - & + & - & - & - & - & + & - & - & - & - & - & - & - & - & - & - & - & 0 & 1 & 0 & 0 \\
\hline 9 & - & - & - & - & - & - & + & - & - & - & - & - & - & - & - & + & - & - & 0 & 3 & 0 & 0 \\
\hline 10 & - & + & - & + & - & - & - & + & + & + & - & + & - & + & + & + & - & + & 0 & 0 & 3 & 0 \\
\hline 11 & - & - & - & + & - & - & - & + & + & + & - & + & - & + & + & + & - & + & 0 & 0 & 5 & 0 \\
\hline 12 & - & - & - & + & - & - & - & + & + & + & - & - & - & + & + & + & - & + & 0 & 0 & 1 & 0 \\
\hline 13 & - & - & - & - & - & - & - & - & - & + & + & + & - & - & - & + & - & - & 0 & 0 & 1 & 0 \\
\hline 14 & - & + & - & - & - & - & - & - & - & + & - & - & - & - & - & - & - & - & 0 & 0 & 0 & 3 \\
\hline 15 & - & - & - & - & - & - & - & - & - & - & - & - & - & - & + & - & - & + & 0 & 0 & 0 & 1 \\
\hline 16 & - & - & - & - & - & - & - & - & - & - & - & - & - & - & - & + & + & - & 0 & 0 & 0 & 2 \\
\hline 17 & - & - & - & - & + & - & - & - & - & - & - & - & - & - & - & + & - & - & 0 & 0 & 0 & 1 \\
\hline 18 & - & - & - & - & + & - & - & - & - & - & - & - & - & - & - & - & - & - & 1 & 0 & 0 & 1 \\
\hline 19 & - & - & - & - & - & - & - & - & - & - & - & - & - & - & - & - & + & - & 0 & 1 & 0 & 1 \\
\hline \multirow[t]{2}{*}{20} & - & - & - & - & - & - & - & - & - & - & - & - & - & $\rightarrow$ & - & - & - & - & 20 & 8 & 1 & 24 \\
\hline & & & & & & & & & & & & & & & & & & & 29 & 22 & 11 & 33 \\
\hline
\end{tabular}

* Numbers correspond to those in table I.

Table III. Patterns of lectin agglutination with cells boiled in glycin- $\mathrm{HCl}$ and their distribution within Lancefield groups

\begin{tabular}{|c|c|c|c|c|c|c|c|c|c|c|c|c|c|c|c|c|c|c|c|c|c|c|}
\hline \multirow{2}{*}{$\begin{array}{c}\text { Pattern } \\
\text { no. }\end{array}$} & \multicolumn{18}{|c|}{ Agglutination with lectins* } & \multicolumn{4}{|c|}{$\begin{array}{c}\text { Number of strains } \\
\text { within Lancefield group }\end{array}$} \\
\hline & 1 & 4 & 7 & 8 & 9 & 10 & 11 & 13 & 14 & 15 & 16 & 17 & 18 & 19 & 21 & 22 & 23 & 24 & $\begin{array}{c}\text { A } \\
(29)\end{array}$ & $\begin{array}{c}\text { B } \\
(22)\end{array}$ & $\begin{array}{c}\mathrm{C} \\
(11)\end{array}$ & $\begin{array}{c}G \\
(33)\end{array}$ \\
\hline 21 & - & + & + & - & - & + & - & - & - & - & - & - & - & - & - & + & - & - & 1 & 0 & 0 & 0 \\
\hline 22 & - & - & - & - & - & - & - & - & - & - & - & - & + & - & - & + & - & - & 1 & 0 & 0 & 0 \\
\hline 4 & - & - & - & - & - & - & - & - & - & - & - & - & - & - & - & + & - & - & 27 & 18 & 0 & 20 \\
\hline 23 & - & + & - & + & - & - & + & - & - & + & - & - & - & + & - & + & - & - & 0 & 1 & 0 & 0 \\
\hline 24 & - & - & - & + & - & - & - & - & - & - & - & - & - & - & - & + & - & - & 0 & 1 & 0 & 0 \\
\hline 25 & + & - & - & - & - & - & - & - & - & - & - & - & - & - & - & + & - & - & 0 & 1 & 0 & 4 \\
\hline 16 & - & - & - & - & - & - & - & - & - & - & - & - & - & - & - & + & + & - & 0 & 1 & 0 & 1 \\
\hline 10 & - & + & - & + & - & - & - & + & + & + & - & + & - & + & + & + & - & + & 0 & 0 & 2 & 0 \\
\hline 11 & - & - & - & + & - & - & - & + & + & + & - & + & - & + & + & + & - & + & 0 & 0 & 1 & 0 \\
\hline 26 & - & + & - & + & - & - & - & + & + & + & - & + & - & - & + & + & - & + & 0 & 0 & 1 & 0 \\
\hline 27 & - & - & - & + & - & - & - & + & + & + & - & + & - & - & + & + & - & + & 0 & 0 & 1 & 0 \\
\hline 28 & - & - & - & + & - & - & - & + & + & + & - & - & - & - & + & + & - & + & 0 & 0 & 3 & 0 \\
\hline 29 & - & - & - & - & - & - & - & + & + & + & - & - & - & - & + & + & - & + & 0 & 0 & 1 & 0 \\
\hline 30 & - & - & - & - & - & - & - & + & + & + & - & - & - & - & - & - & - & + & 0 & 0 & 1 & 0 \\
\hline 31 & - & - & - & - & - & - & - & - & + & + & - & - & - & - & - & + & - & - & 0 & 0 & 1 & 3 \\
\hline 32 & - & - & - & - & - & - & - & - & + & + & - & - & - & - & - & + & - & + & 0 & 0 & 0 & 1 \\
\hline 33 & - & + & - & - & - & - & - & - & + & + & - & - & - & - & - & + & - & - & 0 & 0 & 0 & 1 \\
\hline 34 & - & + & - & - & - & - & - & - & - & + & - & - & - & - & + & + & - & - & 0 & 0 & 0 & 2 \\
\hline \multirow[t]{2}{*}{35} & - & + & - & - & + & + & + & - & - & - & - & - & - & - & - & + & - & - & 0 & 0 & 0 & 1 \\
\hline & & & & & & & & & & & & & & & & & & & 29 & 22 & 11 & 33 \\
\hline
\end{tabular}

* Numbers correspond to those in table 1 .

$\mathrm{HCl}, \mathrm{pH} \mathrm{2,} \mathrm{all} 95$ strains agglutinated with at least one lectin, giving 19 different patterns, four of which (patterns 4, 10, 11 and 16) were identical to those obtained with trypsin-treated cells (table III).

The trypsinised cells of the test strains exhibited three agglutination patterns specific for Lancefield group A, five for group B, four for group C, and four for group $G$ streptococci, comprising $17 \%, 55 \%$,
$91 \%$ and $15 \%$ of strains of each group, respectively (table II). Similarly, lectin agglutination of boiled cells revealed two patterns specific for group A, two for group B, seven for group $\mathrm{C}$ and four for group $\mathrm{G}$, comprising $7 \%, 9 \%, 91 \%$ and $15 \%$ of isolates of each group, respectively (table III).

With both methods, seven lectins (AMA, AMA II, ASA, AUA, NPA, TL and VAA) did not react with 
Table IV. Agglutination of trypsin-treated cells of different Lancefield groups with different lectins

\begin{tabular}{|c|c|c|c|c|c|c|c|c|c|c|c|c|c|c|c|c|c|c|c|}
\hline \multirow{2}{*}{$\begin{array}{l}\text { Lancefield } \\
\text { group }\end{array}$} & \multicolumn{18}{|c|}{ Number of strains that agglutinated with each lectin* } & \multirow{2}{*}{ Tota } \\
\hline & 1 & 4 & 7 & 8 & 9 & 10 & 11 & 13 & 14 & 15 & 16 & 17 & 18 & 19 & 21 & 22 & 23 & 24 & \\
\hline A & 0 & 1 & 0 & 0 & 1 & 0 & 0 & 0 & 0 & 0 & 0 & 0 & 0 & 0 & 0 & 7 & 2 & 4 & 9 \\
\hline B & 1 & 1 & 0 & 0 & 0 & 1 & 11 & 0 & 0 & 0 & 0 & 0 & 0 & 0 & 0 & 4 & 1 & 0 & 14 \\
\hline $\mathrm{C}$ & 0 & 3 & 0 & 9 & 0 & 0 & 0 & 9 & 9 & 10 & 1 & 9 & 0 & 9 & 9 & 10 & 0 & 9 & 10 \\
\hline G & 0 & 3 & 0 & 0 & 2 & 0 & 0 & 0 & 0 & 3 & 0 & 0 & 0 & 0 & 1 & 3 & 3 & 1 & 9 \\
\hline Total & 1 & 8 & 0 & 9 & 3 & 1 & 11 & 9 & 9 & 13 & 1 & 9 & 0 & 9 & 10 & 24 & 6 & 14 & 42 \\
\hline
\end{tabular}

* Numbers correspond to those in table I.

Table V. Agglutination of boiled cells of different Lancefield groups with different lectins

\begin{tabular}{|c|c|c|c|c|c|c|c|c|c|c|c|c|c|c|c|c|c|c|c|}
\hline \multirow{2}{*}{$\begin{array}{l}\text { Lancefield } \\
\text { group }\end{array}$} & \multicolumn{18}{|c|}{ Number of strains that agglutinated with each lectin* } & \multirow{2}{*}{ Total } \\
\hline & 1 & 4 & 7 & 8 & 9 & 10 & 11 & 13 & 14 & 15 & 16 & 17 & 18 & 19 & 21 & 22 & 23 & 24 & \\
\hline A & 0 & 1 & 1 & 0 & 0 & 1 & 0 & 0 & 0 & 0 & 0 & 0 & 1 & 0 & 0 & 29 & 0 & 0 & 29 \\
\hline B & 0 & 2 & 0 & 2 & 0 & 0 & 1 & 0 & 0 & 1 & 0 & 0 & 0 & 1 & 0 & 22 & 1 & 0 & 22 \\
\hline $\mathrm{C}$ & 0 & 3 & 0 & 8 & 0 & 0 & 0 & 10 & 11 & 11 & 0 & 5 & 0 & 3 & 9 & 10 & 0 & 10 & 11 \\
\hline $\mathrm{G}$ & 0 & 8 & 0 & 0 & 1 & 1 & 1 & 0 & 5 & 7 & 0 & 0 & 0 & 0 & 2 & 33 & 1 & 1 & 33 \\
\hline Total & 0 & 14 & 1 & 10 & 1 & 2 & 2 & 10 & 16 & 19 & 0 & 5 & 1 & 4 & 11 & 94 & 2 & 11 & 95 \\
\hline
\end{tabular}

* Numbers correspond to those in table I.

any of the strains tested. When trypsin-treated cells were used, no lectins were found to be specific either for group A or for group $\mathrm{G}$ streptococci. However, the lectin from $M$. amurensis (MAA) reacted with 11 of 22 group B isolates but was non-reactive with other streptococci. In addition, DSA, RPA, CCL, SSL and SNA II were specific for group C streptococci in nine of 11 strains each (table IV). With boiled cells, no lectin was specific for group B, whereas BDA and SNA were specific for one strain of group A each. The lectins RPA and SSL agglutinated 10 and five strains of group $\mathrm{C}$, repectively, in a specific way, while MAA reacted with one strain of group $\mathrm{G}$ (table V). Also, 94 of 95 strains were agglutinated with WGA (table V).

\section{Discussion}

In this study, agglutination by 25 different lectins of $\beta$-haemolytic streptococci, untreated, trypsin-treated or heat-treated, was assessed. Pre-treatment was a prerequisite for agglutination with any lectin and resulted in a reaction of $44 \%$ and $100 \%$ of the strains, respectively. Recently, Slifkin and Doyle described the applications of lectins in clinical microbiology. ${ }^{9}$ For epidemiological purposes, lectins have to agglutinate the strains reproducibly with a certain discriminating power. Although heat-treatment resulted in an agglutination reaction with all strains tested, the discriminating power was rather low since 65 strains yielded the same pattern (pattern 4) (table III). Furthermore, when divided into Lancefield groups, it became evident that, after trypsinisation, it was possible to differentiate $50 \%$ of group B streptococci and $91 \%$ of group $\mathrm{C}$ streptococci with several lectins. The advantage of lectin agglutination studies is that strains can be subtyped in more detail than with Lancefield grouping and biochemical tests alone, hence their usefulness in epidemiological studies.

Lectins bind to specific carbohydrate moieties present on the bacterial wall. ${ }^{3}$ When trypsin or other proteolytic enzymes partially hydrolyse proteoglycans, more carbohydrate residues become available for binding with the lectins. Boiling of the bacteria in $0.25 \mathrm{M}$ glycin- $\mathrm{HCl}$ at $\mathrm{pH} 2$ is a more drastic treatment to degrade the bacterial surface structures. As a result, more glycoconjugates dissolve from the cell wall and cannot be detected by agglutination of the bacteria with lectins. It is likely, therefore, that boiled bacteria are less diverse in respect of their agglutination by lectins. This problem could be solved by the use of lectins coupled to latex spheres so the carbohydrates in solutions can be detected.

Lectin agglutination studies are useful for bacterial surface structure studies. When agglutination assays were performed with boiled cells, WGA reacted with all but one strain, whereas DSA, another GlcNAcbinding lectin, bound to only 10 strains. However, WGA is also able to bind to neuraminyl-residues, whereas DSA cannot, indicating that a sialic acidcontaining structure is present in almost all streptococcal strains, but is only detectable in most cells after boiling at $\mathrm{pH} 2$. Indeed, only 24 strains reacted with WGA after trypsinisation, whereas 94 strains did so after boiling at $\mathrm{pH} 2$. In an earlier study, WGA, at a concentration of $1 \mathrm{mg} / \mathrm{ml}$, agglutinated all group A and $\mathrm{C}$ streptococci and some group $\mathrm{B}$ and $\mathrm{E}$ strains after trypsinisation. Furthermore, it was demonstrated that the lectin interacted with the teichoic acids and peptidoglycan of streptococci. ${ }^{29}$

Whereas WGA is not specific for any one of the Lancefield groups, the lectins from tomato and potato, 
two other lectins with specificity towards GlcNAc and sialic acid, as well as the sialic acid-specific lectin from C. hortensis recognised specifically group B streptococci. $^{7}$ In this study, the lectin from $M$. amurensis (MAA), with specificity for Neu5Ac$\alpha(2,3) \mathrm{Ga}^{30}$ agglutinated group B streptococci only. The lectin from the elder tree (SNA), which is specific for Neu5Ac- $\alpha(2,6)$ GalNAc, ${ }^{31}$ did not react with any of the group B streptococci. It is evident, therefore, that MAA, with the lectins from tomato, potato and $C$. hortensis, can be helpful in differentiating group B streptococci. $^{32}$

The lectins from $H$. pomatia (HPA), D. biflorus (DBA), and $W$. floribunda (WFA), all specific for DGalNAc, agglutinated specifically group C $\beta$-haemolytic streptococci. ${ }^{8,9}$ However, in this study WFA and DBA also reacted with a few strains of other Lancefield groups. The lectins from the phytopathogenic fungus Sclerotinia sclerotiorum, as well as SNA II, both specific for D-GalNAc, reacted with group C streptococci only. The D-GalNAc-binding lectins, APA, CCL and RSA, agglutinated streptococci of other groups in addition to group $C$, whereas the DGalNAc-binding lectins BDA, IRA, and TL did not react with these organisms. On the other hand, only

\section{References}

1. Goldstein IJ, Hughes RC, Monsigny M, Osawa T, Sharon N. What should be called a lectin? Nature $1980 ; 285: 66$.

2. Damjanov I. Biology of disease. Lectin cytochemistry and histochemistry. Lab Invest 1987; 57: 5-20.

3. Pistole TG. Interaction of bacteria and fungi with lectins and lectin-like substances. Annu Rev Microbiol 1981; 35: 85-112.

4. Köhler W, Prokop O, Kühnemund O. Routine identification of group-C streptococci by means of an agglutinin (protectin) from the albumen gland of the edible snail, Helix pomatia. J Med Microbiol 1973; 6: 127-130.

5. Ottensooser F, Nakamizo Y, Sato M, Miyamoto Y, Takizawa $\mathrm{K}$. Lectins detecting group $\mathrm{C}$ streptococci. Infect Immun 1974; 9: 971-973.

6. Wagner M. Agglutination of bacteria by a sialic acid-specific lectin of the snail Cepaea hortensis. Acta Histochem 1982; 71: 35-39.

7. Slifkin M, Cumbie R. Identification of group B streptococcal antigen with lectin-bound polystyrene particles. $J$ Clin Microbiol 1987; 25 : 1172-1175.

8. Aitchison EJ, Lambert PA, Farrell ID. Antigenic composition of an endocarditis-associated isolate of Streptococcus faecalis and identification of its glycoprotein antigens by ligand blotting with lectins. J Med Microbiol 1986; 21: 161-167.

9. Slifkin M, Doyle RJ. Lectins and their application to clinical microbiology. Clin Microbiol Rev 1990; 3: 197-218.

10. O'Sullivan N, Benjamin J, Skirrow MB. Lectin typing of Campylobacter isolates. J Clin Pathol 1990; 43: 957-960.

11. Moyes A, Young $\mathbf{H}$. An analysis of lectin agglutination as a means of sub-dividing gonococcal serovars. J Med Microbiol 1992; 37: 51-55.

12. Jarløv JO, Hansen J-ES, Rosdahl VT, Espersen F. The typing of Staphylococcus epidermidis by a lectin-binding assay. $J$ Med Microbiol 1992; 37: 195-200.

13. Lotan R, Skutelsky E, Danon D, Sharon N. The purification, composition, and specificity of the anti-T lectin from peanut (Arachis hypogaea). J Biol Chem 1975; 250: 8518-8523.

14. Peumans WJ, Nsimba-Lubaki M, Peeters B, Broekaert WF. Isolation and partial characterization of a lectin from group $\mathrm{C}$ streptococci were agglutinated by the lectin from $D$. stramonium, specific for GlcNAc, as well as by the lectin from Robinia pseudoacacia, which has a complex specificity.

The results of the present study indicate that, although some lectins show the same specificity, there is a difference in agglutination activity with different bacteria. Indeed, the carbohydrate-binding activity of most lectins is tested in inhibition studies with simple sugars. However, the carbohydrate most haptenic to the binding site of the lectin has often a more complex structure. Therefore, when lectins are used in structural studies of bacterial walls, it is useful to know their binding specificity in more detail. When the detailed specificity of the lectins if not fully known, the lectin agglutination assay is a cheap and versatile tool for subtyping micro-organisms in the clinical and epidemiological setting. It provides more detailed information than serological techniques or conventional biochemical tests. Moreover, the technique requires neither apparatus nor highly qualified technologists and is less laborious and time-consuming than analyses of proteins or nucleic acids.

We thank M. Vliegen for his practical assistance. ground elder (Aegopodium podagraria) rhizomes. Planta 1985; 164: 75-82.

15. Van Damme EJM, Goldstein IJ, Peumans WJ. A comparative study of related mannose-binding lectins from Amaryllidaceae and Alliaceae species. Phytochemistry 1991; 30: $509-514$.

16. Peumans WJ, Nsimba-Lubaki M, Carlier AM, Van Driessche E. A lectin from Bryonia dioica root stocks. Planta 1984; 160: 222-228.

17. Broekaert WF, Peumans WJ, Allen AK. Carbohydrate binding proteins from Datura stramonium seeds. In: Bøg-Hansen TC, Breborowicz J (eds) Lectins, vol 4. Berlin, New York, Walter de Gruyter Co. 1985; 481-489.

18. Kawaguchi T, Matsumoto I, Osawa T. Studies on hemagglutinins from Maackia amurensis seeds. J Biol Chem 1974; 249: 2786-2792.

19. Wantyghem J, Goulut C, Frénoy J-P, Turpin E, Goussault Y. Purification and characterization of Robinia pseudoacacia seed lectins. A re-investigation. Biochem $J$ 1986; 237: 483-489.

20. Kellens JTC, Peumans WJ. Occurrence of lectins in different strains of Rhizoctonia solani. In: Kocourek J, Freed DJL (eds) Lectins, vol. 7. St Louis, Sigma Chemical Co. 1990; $57-62$.

21. Kellens JTC, Goldstein IJ, Peumans WJ. Lectins in different members of the Sclerotiniaceae. Mycol Res 1992; 96: 495-502.

22. Kaku H, Peumans WJ, Goldstein IJ. Isolation and characterization of a second lectin (SNA-II) present in elderberry (Sambucus nigra L.) bark. Arch Biochem Biophys 1990; 277: 255-262.

23. Cammue BPA, Peeters B, Peumans WJ. A new lectin from tulip (Tulipa) bulbs. Planta 1986; 169: 583-588.

24. Kurokawa T, Tsuda M, Sugino $Y$. Purification and characterization of a lectin from Wisteria floribunda seeds. $J$ Biol Chem 1976; 251 : 5686-5693.

25. Nagata Y, Burger MM. Wheat germ agglutinin. Molecular characteristics and specificity for sugar binding. $J$ Biol Chem 1974; 249 : 3116-3122.

26. Agrawal BBL, Goldstein IJ. Protein-carbohydrate interaction. VI. Isolation of concanavalin A by specific adsorption on cross-linked dextran gels. Biochim Biophys Acta 1967; 147: 262-271.

27. Etzler ME, Kabat EA. Purification and characterization of a 
lectin (plant hemagglutinin) with blood group A specificity from Dolichos biflorus. Biochemistry 1970; 9: 869-877.

28. Ziska P, Franz H, Kindt A. The lectin from Viscum album $\mathrm{L}$. purification by biospecific affinity chromatography. Experientia 1978; 34: 123-124.

29. Wagner M. Interaction of wheat-germ agglutinin with streptococci and streptococcal cell wall polymers. Immunobiology 1979; 156: 57-64.

30. Knibbs RN, Goldstein IJ, Ratcliffe RM, Shibuya N. Characterization of the carbohydrate binding specificity of the leukoagglutinating lectin from Maackia amurensis. $J$ Biol Chem 1991; 266: 83-88.

31. Shibuya N, Goldstein IJ, Broekaert WF, Nsimba-Lubaki M, Peeters B, Peumans WJ. The elderberry (Sambucus nigra L.) bark lectin recognizes the $\operatorname{Neu} 5 \operatorname{Ac}(\alpha 2-6)$ GalNAc sequence. J Biol Chem 1987; 262: 1596-1601.

32. Lim DV, Morales WJ, Walsh AF, Kazanis D. Reduction of morbidity and mortality rates for neonatal group B streptococcal disease through early diagnosis and chemoprophylaxis. J Clin Microbiol 1986; 23: 489-492. 